graduate in horticulture at the end of this second year should have some idea of what original investigation means, of the necessity for the highest standard of honesty and truthfulness, of the importance of basing opinions on evidence and of the fact that the scientific method can be used to obtain information at all levels. They also have had a good grounding in an unusually wide range of sciences, both taught in other departments and integrated here into the technology which is horticulture; these lie beyond the scope of the present article, but they add much to the merits of the course for the production of teachers. A number of our horticulture graduates have become teachers of biology, rural science and other science subjects, and I should like to see the proportion increase.

The honours students in horticultural science stay for a further year; this includes a more advanced course of statistics (given by the Unit of Biometry), and for each student a small independent experimental investigation with analysis of the data and their discussion, together with the relevant literature, in a short dissertation. This last is a feature common to the final year of many honours courses, but I should like to record my opinion that it does more to enable a student to think independently and teach himself than any other part of the course. By the end of his second year (post-intermediate) he should have a fair store of factual knowledge, and we devote a large part of the final year to trying to help him to use this and make further advances for himself.

These honours horticultural science graduates would, of course, be even more suitable for teaching, and I hope that in future some may be attracted to the profession; so far most have proceeded to research and the others have entered the National Agricultural Advisory Service or become technical experts to large growers.
In the "Nuffield Biology Teaching Project".2 the importance of more quantitative and experimental work in school biology is emphasized. It is proposed to provide: "A book of projects intended for the most gifted students and those who show particular aptitude and enthusiasm for experimental work"2. It is, of course, entirely right that the most gifted students should be given every opportunity to extend their abilities, but $I$ am suggesting that all students should take part in some original experimentation in the hope and belief that it will stimulate more of them to discover in themselves an "aptitude and enthusiasm for experimental work". It is asking a great deal of the teachers that they should organize a proportion of original experiments year after year unless they have themselves had experience of original work in experimental science. For this reason, if for no other, the financial support given by the Royal Society to research by school teachers is most important. If, in the biological departments of universities, the staffs are to increase over a long term in the manner foreshadowed by the Robbins Report, the schools must provide human material of the best possible kind-it is necessary and only fair that the universities should give very serious thought to the best methods of providing teachers for the schools.

Since writing this article I have seen the interesting account of the Gulbenkian-sponsored enquiry into practical work in school seience ${ }^{3}$. I consider that experimental horticulture provides the opportunity for the type of teaching that the enquiry team is seeking.

${ }^{1}$ Fisher, R. A., Statistical Methods for Research Workers (Edinburgh, 19251950 )

"Dowdswell, W. H., Kelly, P. J., and Perrott, E., Inst. Biol. J., 10, 71 (1963). ${ }^{3}$ Kerr, J. F.. Boulind, H. F., Rolls, M. J., Scott, D. W., and Stafford, E., Pratical Work in School Science (Leicester, 1963).

\title{
OBITUARY
}

\section{Prof. R. K. Morton}

ON September 27 occurred the tragic death, at the age of forty-three, of Robert Kerford Morton, professor of biochemistry in the University of Adelaide, as a result of an explosion in his laboratory. It appears that the collapse of a filter flask under vacuum produced a spray of acetone which was ignited by a spark from an electric fan; Morton eaught the full force of tho explosion, was severely burned, and died three days later without recovering consciousness. That this brilliant and distinguished biochemist and enzymologist should be suddenly cut off at the height of his powers is a tragedy for A.ustralian science and indeed for the whole scientific world.

Morton was born in A.ustralia in August 1920 and was educated at Sydney Boys' High School and later at Hawkesbury A.gricultural College, New South Wales, where he took the diploma in dairying. In 1940 he entered the University of Sydney to read agricultural science, but broke off his course to enlist in the Royal Australian Navy. In 1941 he was transferred to the Royal Navy, where he had a distinguished career as an anti-submarine officer. He was demobilized in 1945 with the rank of lieutenant-cornmander and immediately resumed his university courso, graduating in 1947 with first-class honours and a University Medal. During this time he also organized a testing laboratory for the New South Wales Milk Board, and with Prof. J. M. Vincent carried out an important survey of the factors affecting the quality of milk supplies, publishing the first of a series of joint papers with Prof. Vincent before he graduated. $\mathrm{He}$ was awarded a research fellowship in the University of Sydney.
In 1949 he became the first holder of the Gowrie travelling scholarship. This enabled him to como to work in the Department of Biochemistry of the University of Cambridge, where he joined my Sub-Department as a research student, taking his Ph.D. degree in 1952. During this period he developed an intense interest in enzymes, and this greatly influenced the whole subsequent course of his work. His outstanding abilities for research quickly became apparent. Within a short time he had obtained several very highly purified phosphatases and carried out work with them which did much to clear up the phosphatase field. A.t the same time, he discovered the butanol method for extracting so-called 'insoluble' enzymes from intracellular particles, which opened up many possibilities and has since been widoly and successfully used. He also did important work on the group-transferring abilities of hydrolysing enzymes.

In 1952 he accepted an invitation from Prof. V. M. Trikojus to become senior lecturer in biochemistry in the University of Melbourne, where he was soon made a reader and in 1956 associate professor of plant biochemistry. Here he began what was probably his most brilliant work, namely, the study of the lactate dehydrogenase of yeast, on which he was still working at the time of his death. He succeeded in obtaining the pure enzyme in the form of large red erystals and showed that it was identical with the hæmoprotein, eytochrome $b_{2}$. It was, in fact, the first cytochrome to be crystallized; but he found surprisingly that it was also a flavoprotein, containing one flavin group for each hæm group. This was the first examplo of a protein containing two different coloured prosthetic groups, both essential for enzyme activity. But in addition Morton showed that the enzyme was present in the crystals in combination with a new 
kind of deoxyribonucleic acid (not necessary for activity) which was of special interest because it was of comparatively low molecular weight and because it was situated outside the cell nucleus. He prepared a beautiful series of crystalline derivatives, each lacking one or more of the three groups, and with these he carried out elegant investigations of the mechanism of the enzyme.

Not all this work was done at Melbourne. In 1957 he accepted a pressing invitation to become professor of agricultural chemistry in the Waite Agricultural Institute at Adelaide. Here he rapidly built up a first-class research group. Under his dynamic and inspiring leadership his department burst into activity on a number of different fronts, quickly acquiring an international reputation and attracting distinguished research workers from other countries. His next five years were incredibly productive. His own work included investigations, not only on cytochrome $b_{2}$, but also on the activities of microsomes and mitochondria of plant cells, on the biosynthesis of coenzymes, on the free energies of some important biochemical reactions, on the chemical control of cell division in relation to tumours, on protein synthesis in vitro by particles from plant cells at the expense of phytic acid, and on many other subjects of great biological interest. In addition, he inspired much work by others in his department.

He spent most of 1962 in England with a professorial fellowship in the University of Nottingham under the Commonwealth Interchange Scheme, travelling a good deal in order to give a fascinating series of lectures. During this time he received an invitation to the chair of biochemistry in the University of Adelaide, which he accepted. At the time of his death he had only been a year in his new department, but he had already left the mark of his invigorating influence on it.

Bob Morton will be remembered with affection for his endearing qualities by a large circle of friends throughout the world. He was a delightful companion, full of zest for life, gay, humorous, unselfish, humble, keenly interested in a wide variety of things and able to inspire the same interest in others. His fine character was founded on high Christian principles. I count it a privilege to have known him.

He was very happy in his home life, and his untimely death is especially tragic for his wife and two young sons. MaLColm Dixon

\section{NEWS and VIEWS}

\section{Inorganic Chemistry and the Agricultural Research Council's Unit of Nitrogen Fixation at Queen Mary College, London: Prof. J. Chatt, F.R.S.}

DR. J. Chatr has boen appointed to the new ehair of inorganic chemistry at Queen Mary College, University of London. $\mathrm{He}_{\Theta}$ will also continue as director of the Agricultural Research Council's Unit of Nitrogen Fixation, which is now being established at Queen Mary College to investigate both the chemical and microbiological sides of the mechanism of nitrogen fixation. A separate building is to be constructed for the Unit close to the new building now being started for the Chemistry Department of the College. Dr. J. R. Postgate, previously at the Microbiological Research Establishment, Porton, is in charge of the Unit's microbiological side, and is at present working at the Royal Veterinary College of the University of London. Dr. Chatt was educated at Nelson School, Wigton, and Emmanuel College, Cambridge, where his first research work was supervised by Dr. F. G. Mann. Since then he has gained an international reputation for his work on the co-ordination chemistry of the transition elements, being particularly associated with synthetic and structural problems of organo-metallic complexes and complexes containing as ligands alkenes, alkynes, hydride ion and the organic derivatives of arsenic and phosphorus. Apart from a year as an Imperial Chemical Industries Research Fellow at the Imperial College of Science and Technology in 1946-47, his career has hitherto been mainly in industry, though he has held temporary appointments as visiting professor in the United States at Pennsylvania State University in 1959 and at Yale University in 1963. After short periods with Woolwich Arsenal and Peter Spence, Ltd., he joined Imperial Chemical Industries, Ltd., and from 1947 until 1963 he was successively head of the Inorganic Chemistry Department of the Butterwick (later Akers) Research Laboratories, group manager in the Research Department of the Heavy Organic Chemicals Division, and finally group head and research consultant in the Petrochemical and Polymer Laboratory. He was elected a Fellow of the Royal Society in 1961, and is vice-president of the Chemical Society and a member of the Commission on Nomenclature of Inorganic Chemistry of the International Union of Pure and Applied Chemistry. Among such previous work for scientific societies, it is notable that he originated the present bi-annual series of International Conferences on Co-ordination Chemistry by a symposium which he organized at Welwyn in 1950 .

Physics at the University of Edinburgh:

Prof. W. Cochran, F.R.S.

Dr. W. Cochran has been appointed to a newly instituted additional ehair of physics in the University of Edinburgh. Dr. Cochran was born in Newton Mearns, Renfrewshire, in 1922, and educated at Boroughmuir School, Edinburgh, and at the Universities of Edinburgh and Cambridge. In 1943, he graduated B.Sc. in the University of Edinburgh, with honours in physics, and, in 1946, he graduated Ph.D. in the same University. Later. he graduated M.A. in the University of Cambridge. From 1943, he was for three years assistant lecturer in the Department of Physics in the University of Edinburgh, and from 1948 until 1962 he was demonstrator and lecturer in physies in the University of Cambridge. Dr. Cochran is a Fellow of Trinity Hall, Cambridge, and has been University reader since 1962, in which year he was elected a Fellow of the Royal Society of London. During periods of academic leave from Cambridge, he has held fellowships from the Rockefeller Foundation and from Atomic Energy of Canada. Dr. Cochran's research in Cambridge has been concerned with the structure of molecules, particularly of those related to deoxyribonucleic acid (DNA). More recently, his interest has been in the use of neutrons to investigate interatomic forces in crystals, and the electrical properties of crystals. Much of his research in this field has been done in collaboration with scientists at Atomic Fnergy of Canada, and at Harwell. Dr. Cochran will take up his appointment to the additional chair of physies on October 1 .

\section{Sociology at the University of Manchester:}

Prof. P. M. Worsley

Dr. P. M. Worscey, senior lecturer in sociology in the University of Hull, has been appointed to the chair of sociology in the University of Manchester from a date to be arranged. Dr. Worsley was educated at St. Francis Xaviers College, Liverpool, and Wallasey Grammar School, and in 1942 was awarded an Exhibition to Emmanuel College, Cambridge, where he read the English Tripos. He entered the Services in 1943 and served in 